Sains Malaysiana 47(7)(2018): 1571-1578

http://dx.doi.org/10.17576/jsm-2018-4707-27

\title{
Microwave Technique for Moisture Content and pH Determination during Pre- Harvest of Mango cv. Chok Anan
}

(Teknik Mikro Ketuhar untuk Kandungan Lembapan dan Penentuan pH Semasa Pra-Tuaian Mangga cv. Chok Anan)

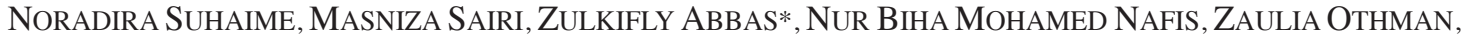 \\ AMIR SYARIFFUDDEEN MHD ADNAN, AMIR REDZUAN SHAMSULKAMAL, \\ SURIATI PAIMAN \& TITY NAZLEEN MOHAMED
}

\begin{abstract}
The maturity of mango is usually assessed by the determination of its moisture content (m.c.), soluble solid content (SSC) and $\mathrm{pH}$. However, these techniques are either time consuming, tedious or destructive. In this research, we extend the application of the open-ended coaxial probe technique to determine m.c. and pH of Chok Anan mango from its dielectric properties from week 5 to week 17 after anthesis. The effects of frequency and m.c. on the values of the dielectric constant and loss factor were also investigated. The critical frequency separating the different polarizations was found to be inversely proportional to m.c. Also, in this research we proposed a new classification of fruit ripeness related to the number of weeks after anthesis. The actual dielectric properties, m.c., SSC and pH of Chok Anan mango were measured using standard methods. Relationships were established between the dielectric constant, loss factor, critical frequency, pH and m.c. The accuracy for the determination of m.c. and pH using the coaxial probe was within $1.7 \%$ and $3.0 \%$, respectively.
\end{abstract}

Keywords: Dielectric; loss factor; moisture content; open-ended coaxial probe; $p H$

\section{ABSTRAK}

Kematangan mangga biasanya ditentukan oleh kandungan lembapan (m.c.), kandungan pepejal larut (SSC) dan pH. Walau bagaimanapun, teknik ini memakan masa yang lama, rumit atau merosakkan buah. Dalam penyelidikan ini, kami memperluaskan penggunaan teknik pengesan sepaksi terbuka untuk menentukan m.c. dan pH mangga Chok Anan daripada sifat dielektriknya dari minggu 5 hingga minggu 17 selepas pendebungaan. Kesan frekuensi dan m.c. pada nilai dielektrik dan faktor kehilangan juga dikaji. Frekuensi kritikal yang memisahkan polarisasi yang berbeza didapati berkadar songsang dengan m.c.. Selain itu, dalam penyelidikan ini kami mencadangkan pengelasan terbaharu untuk kematangan buah yang berkaitan dengan bilangan minggu selepas pendebungaan. Sifat dielektrik, m.c., SSC dan pH mangga Chok Anan yang sebenar diukur menggunakan kaedah piawai. Hubungan antara nilai dielektrik, faktor kehilangan, frekuensi kritikal, pH dan m.c. telah dibangunkan. Ketepatan untuk penentuan m.c. dan pH menggunakan pengesan sepaksi terbuka masing-masing adalah sebanyak $1.7 \%$ dan $3.0 \%$.

Kata kunci: Dielektrik; faktor kehilangan; kandungan lembapan; pengesan sepaksi terbuka; pH

\section{INTRODUCTION}

Mango (Mangifera indica L.) is a popular fruit of the tropics. It belongs to Anacardiaceae family with 60 genera (Abidin 1991). The Malaysian National Agricultural Policy (NAP) has enlisted it among the 15 types of fruits under agricultural produce export (Ding \& Darduri 2013). Therefore, fruit quality assessment is crucial and commonly conducted based on the external properties such as size, color, shape and defect. However, they may inaccurately represent the internal quality such as sugar content, acidity, firmness and internal breakdowns (Soltani et al. 2011).

In the assessment of agricultural produce, the measurement of moisture content (m.c.) remains the prime interest (Ragni et al. 2006) besides soluble solid content (SSC) and pH. Appiah et al. (2011) reported that moisture percentage for ripe and unripe mango is $79.75 \%$ and
$83.11 \%$, respectively. Generally, $\mathrm{pH}$ also increases during fruit development typically from 4.2 to 5.7 (Pleguezuelo et al.2012), meanwhile SSC increases during the ripening stage (Padda et al. 2011). However, the techniques to determine m.c., $\mathrm{pH}$ and SSC are either time consuming, tedious and destructive.

Recently, a speedy and non-destructive technique using microwave open-ended coaxial probe was applied to determine the dielectric properties of mango from 1.0 $\mathrm{MHz}$ to $1.8 \mathrm{GHz}$. Sosa-Morales et al. (2009) reported that several parameters were measured such as m.c., soluble solids, acidity, $\mathrm{pH}$, maturity index and electrical conductivity of mango. However, the results were reported only for post-harvested mangoes on day $0,4,8$ and 16 of storage. No information was provided during fruit developmental stage. In addition, Sosa-Morales et al. (2009) only conducted measurements below $1.8 \mathrm{GHz}$ 
where the effect of bound water is predominant. The loss factor, $\varepsilon$ " depends on the operating frequency. Initially, $\varepsilon$ " value decreases with frequency from direct current (DC) to a critical frequency separating the bound and free water molecules under the influence of both the dipolar relaxation and ionic conduction. Beyond $1.8 \mathrm{GHz}$, the measurements are greatly influenced by the free water relaxation and $\varepsilon$ " increases with the increasing frequency.

Contrary to Sosa-Morales et al. (2009), this study focused on the dielectric and physicochemical properties of mango during fruit development starting week 5 to week 17 after anthesis. Anthesis is the period where the flower bud of a plant is fully opened and functional (Guardiola 1997). The study examined the dielectric properties in the frequency range from DC to $4.0 \mathrm{GHz}$ covering the dipolar relaxation, ionic conduction and free water relaxation behavior. The objectives of this study were: to determine the variation in m.c., $\mathrm{pH}$ and SSC with weeks after anthesis during fruit development process, to determine the effect of frequency on the dielectric constant, $\varepsilon$ ' and loss factor, $\varepsilon$ " of mango, to establish the relationship between the critical frequency, $\varepsilon^{\prime}, \varepsilon^{\prime \prime}$ and $\mathrm{pH}$ with m.c. and to extend the application of open-ended coaxial technique to determine both m.c. and $\mathrm{pH}$ of fruits. These relationships can be used to predict the ripeness stage of mango.

\section{MATERIALS AND METHODS}

\section{SAMPLE PREPARATION}

The experimental design was a randomization design in which the experiment used 5 randomly selected Chok Anan mango trees. Fifty five fresh (Mangifera indica cv. Chok Anan) mango samples were picked at 2-week intervals starting week 5 to week 9 after fruiting and continued with 1-week interval until week 17 (April to June 2016) from mango plot at MARDI Research Station, Kundang, Selangor, Malaysia. The controlled variable was implemented by continuously monitoring the ripeness of mango samples from the same tree. In every experiment, five mango samples were picked from five randomly selected mango trees (one sample per tree). The physicochemical properties of mango such as m.c., SSC and pH were then measured. All the mangoes were washed and sliced into the size of $2.0 \times$ $3.0 \mathrm{~cm}$ without removing the skin. The thickness for each sample was $1.5 \mathrm{~cm} .195$ sample slices were obtained for 55 mangoes from week 5 to week 17. Data were analyzed using analysis of variance (ANOVA) (SAS Institute 1989).

\section{MOISTURE CONTENT MEASUREMENT}

The microwave oven-drying method was used to determine the actual m.c. of mango using the official AOAC method (AOAC 2000; Nielsen 2010) with two minor modifications on time and power setting. Each sample was dried for 20 min with $550 \mathrm{~W}$ microwave power satisfying the minimum requirement for water (Michael et al. 1991). The dried samples were cooled at room temperature of $25^{\circ} \mathrm{C}$ before being weighed again. Prior the drying procedure, each part was weighed separately using a Shimadzu Y220 electronic weight balance (Shimadzu Corporation, Japan) with 0.1 mg precision. The process was repeated until a constant mass $\pm 0.5 \mathrm{mg}$ was obtained for each sample (Yahaya et al. 2014). The wet basis m.c. of a material is defined as Bouraoui et al. (1993):

$$
\text { Moisture content }(\%)=\frac{m_{w e t}-m_{d r y}}{m_{w e t}} \times 100 \%
$$

where $m_{w e t}$ and $m_{d r y}$ are the initial mass before drying and the final mass after drying, respectively.

\section{MEASUREMENT OF THE DIELECTRIC PROPERTIES}

The dielectric properties were measured using Agilent (now Keysight Technologies) 85070B open-ended coaxial (OEC) probe (Keysight Technologies, Inc., California) along with a HP 8720B Vector Network Analyzer (VNA) (Keysight Technologies, Inc., California) for 201 frequency points ranging from 1.0 to $4.0 \mathrm{GHz}$. Permittivity (dielectric constant and loss factor) was calculated from the reflection coefficient of the material in contact with the active tip of the probe (Blackham \& Pollard 1997). The calibration standards for the dielectric probe were air, a shorting block and deionized water. The measurement error for the dielectric constant was \pm 0.05 (Agilent Technologies 2013). 195 samples were used for the dielectric properties measurement. The samples were supported using a laboratory jack that was raised to bring the sample into firm and close contact with the sensor. The coaxial cable and sensor were fixed using a retort stand since any subtle movement could affect the measurement results. The minimum thickness, of the sample to avoid the microwave signal reach the end face of the sample using OEC probe is specified by the manufacturer (Agilent Technologies 2013) as,

$$
d=\frac{20}{\sqrt{\varepsilon^{*}}}(\mathrm{~mm})
$$

where represents permittivity.

The lowest $\varepsilon^{*}$ that can be measured by OEC probe is 2.0 , equivalent to the sample thickness $1.4 \mathrm{~cm}$. The thickness will be smaller for samples with higher dielectric constant values according to (2). In this work, measurements were carried out to determine the exact minimum thickness of the mango flesh. The values of the dielectric constant of sample were found to be constant if the thickness was above $0.8 \mathrm{~cm}$. Thus, the presence of the stone will have negligible effect on the permittivity measurement of the flesh if the samples were thicker than $0.8 \mathrm{~cm}$.

\section{DETERMINATION OF SSC AND PH}

SSC is used as a measure of sweetness and it is determined by measuring the juice (Guo et al. 2011). The mango juice was expressed using juice extractor for the SSC measurement. The SSC was determined with a 13950000 
AR 200 digital refractometer (Reichert Inc., New York, USA) following method 932.12 of AOAC (1990). The refractometer readings which are frequently referred to as Brix readings are expressed in percent of total soluble solids by weight (Nelson 2003). Meanwhile the $\mathrm{pH}$ value was determined with a SG2-FK pH Meter (Mettler-Toledo, Schwerzenbach, Switzerland) by following the procedure of AOAC (1990), method 981.12. The measurement of every sample was conducted in three replications which then averaged.

\section{RESULTS AND DISCUSSION}

\section{MANGO PHYSIOLOGY AND RIPENING}

Figure 1 shows the variations in m.c., SSC and $\mathrm{pH}$ during the fruit development from week 5 to 17 , meanwhile Table 1 shows the list of the values. However, these values depend on numerous factors such as cultivator, climatic and cultural factors (Quintana et al. 1984). To date, various classifications of fruit ripeness stage have been proposed. At an orchard, fruit ripeness is usually categorized into three stages i.e. unripe, half ripe and fully ripe. In this work, the mango samples were categorized into four stages based on the \% m.c. since the m.c. can be measured non-destructively using microwave technique. Mangoes were sliced without removing the skin to determine the relationship of m.c. and permittivity for all regions. Once the calibration equation has been established, m.c. of the whole mango can be determined non-destructively using an OEC sensor from calibration equations relating m.c. to the measured permittivity.

The analysis of variance (ANOVA) in Table 2 suggests the best relationship between m.c. and ripening stages with $p$-value $=2.55 \times 10^{-19}$ as compared to $\operatorname{SSC}(p$-value $=$ $0.126484)$ and $\mathrm{pH}\left(p\right.$-value $\left.=8.88 \times 10^{-07}\right)$.

The regression equations relating to m.c., SSC and $\mathrm{pH}$ with time (fruit development weeks) are shown in Figure 1. These equations can be used to predict m.c., SSC and $\mathrm{pH}$ during fruit development and ripening between 5 and 17 weeks after anthesis. The study showed that during the fruit development and ripening from week 5 to week 17, the m.c., $\mathrm{SSC}$ and $\mathrm{pH}$ have increased. The m.c., $\mathrm{SSC}$ and $\mathrm{pH}$ of the ripe Chok Anan mango (averaged over five samples) at week

TABLE 1. M.C., SSC and pH of mango samples

\begin{tabular}{|c|c|c|c|c|c|}
\hline $\begin{array}{c}\text { Maturity/ ripeness } \\
\text { stage }\end{array}$ & & $\begin{array}{l}\text { Time } \\
\text { (week) }\end{array}$ & $\begin{array}{c}\text { m.c. }(\%) \\
( \pm \text { std. dev.) }\end{array}$ & $\begin{array}{c}\text { SSC (Bx) } \\
( \pm \text { std. dev.) }\end{array}$ & $\begin{array}{c}\mathrm{pH} \\
( \pm \text { std. dev. })\end{array}$ \\
\hline \multirow{7}{*}{ Unripe } & 5 & \multirow{3}{*}{ Stage 1} & $72.72 \pm 0.16$ & $6.45 \pm 0.25$ & $2.79 \pm 0.04$ \\
\hline & 7 & & $73.31 \pm 0.02$ & $6.88 \pm 0.24$ & $2.99 \pm 0.14$ \\
\hline & 9 & & $74.47 \pm 0.15$ & $6.25 \pm 0.35$ & $3.59 \pm 0.40$ \\
\hline & 10 & \multirow{3}{*}{ Stage 2} & $76.41 \pm 0.37$ & $5.50 \pm 0.86$ & $3.40 \pm 0.36$ \\
\hline & 11 & & $78.39 \pm 0.45$ & $5.44 \pm 0.43$ & $3.52 \pm 0.23$ \\
\hline & 12 & & $81.19 \pm 0.34$ & $5.84 \pm 0.82$ & $3.64 \pm 0.17$ \\
\hline & 13 & \multirow{3}{*}{ Stage 3} & $82.30 \pm 0.25$ & $6.39 \pm 0.52$ & $3.85 \pm 0.43$ \\
\hline \multirow[t]{2}{*}{ Half-ripe } & 14 & & $83.07 \pm 0.05$ & $6.84 \pm 0.36$ & $3.90 \pm 0.11$ \\
\hline & 15 & & $84.45 \pm 0.17$ & $7.87 \pm 0.25$ & $3.93 \pm 0.16$ \\
\hline \multirow[t]{2}{*}{ Full-ripe } & 16 & \multirow{2}{*}{ Stage 4} & $86.46 \pm 0.22$ & $17.83 \pm 0.87$ & $4.25 \pm 0.02$ \\
\hline & 17 & & $88.11 \pm 0.50$ & $20.20 \pm 1.37$ & $4.83 \pm 0.31$ \\
\hline
\end{tabular}

TABLE 2. Statistical analysis using ANOVA for (a) m.c., (b) SSC and (c) pH

\begin{tabular}{|c|c|c|c|c|c|c|c|}
\hline \multicolumn{8}{|l|}{ ANOVA } \\
\hline Parameters & $\begin{array}{l}\text { Source of } \\
\text { Variation }\end{array}$ & SS & df & MS & $\mathrm{F}$ & P-value & F crit \\
\hline \multirow{3}{*}{ m.c. } & Between groups & 25696.52 & 1 & 25696.52 & 1196.957 & $2.55 \times 10-19$ & 4.351244 \\
\hline & Within groups & 429.3642 & 20 & 21.46821 & & & \\
\hline & Total & 26125.89 & 21 & & & & \\
\hline \multirow{3}{*}{ SSC } & Between groups & 52.57637 & 1 & 52.57637 & 2.542734 & 0.126484 & 4.351244 \\
\hline & Within groups & 413.5421 & 20 & 20.6771 & & & \\
\hline & Total & 466.1185 & 21 & & & & \\
\hline \multirow{3}{*}{$\mathrm{pH}$} & Between groups & 354.4844 & 1 & 354.4844 & 48.7777 & $8.88 \times 10^{-07}$ & 4.351244 \\
\hline & Within groups & 145.3469 & 20 & 7.267345 & & & \\
\hline & Total & 499.8313 & 21 & & & & \\
\hline
\end{tabular}



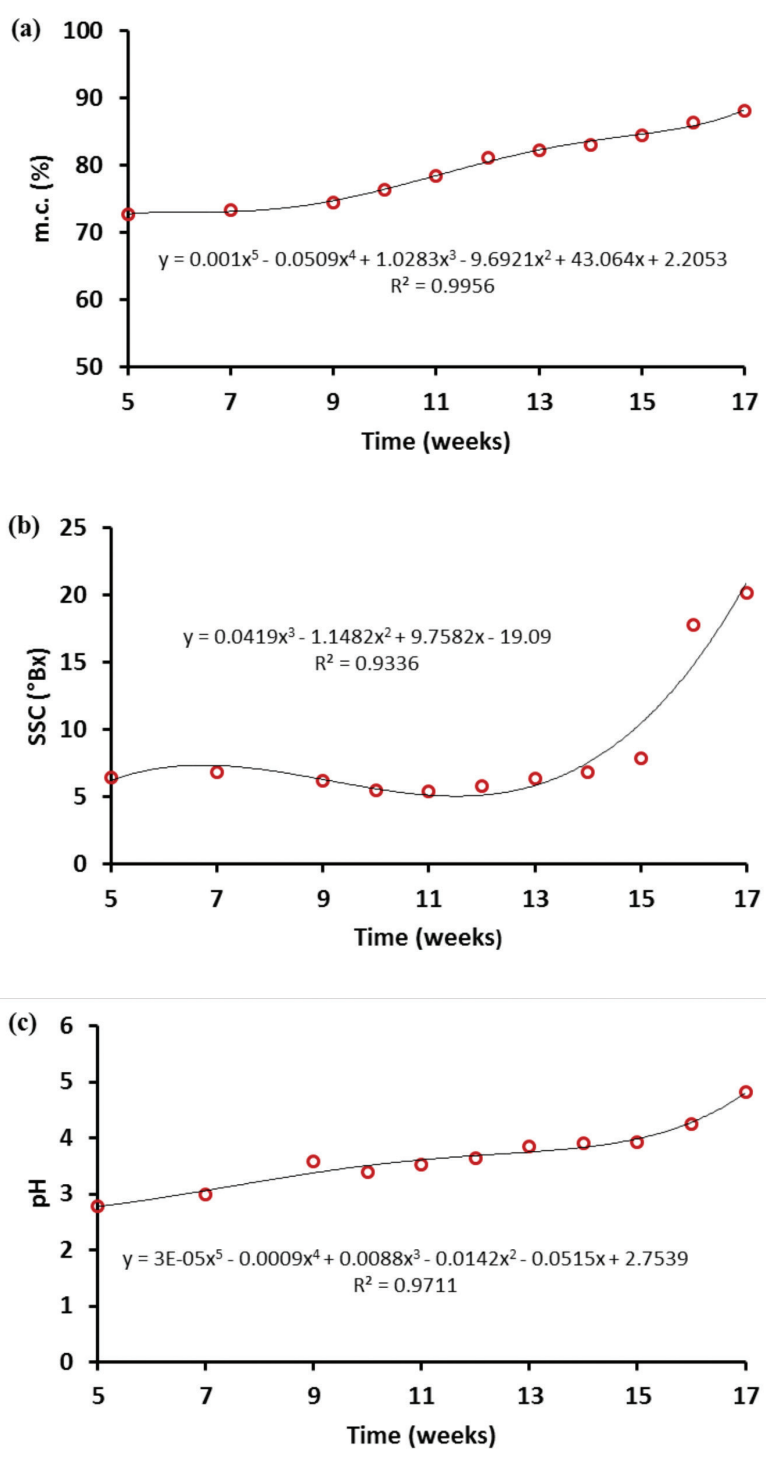

FIGURE 1. Relationship between (a) m.c., (b) SSC and (c) pH with time (week) during the ripening stages of mango

17 were $88.11 \%, 20.20^{\circ}$ Brix and 4.83 , respectively. The results were close to the reported m.c. of $88.67 \%$ (Shofian et al.2011), SSC of $16.1^{\circ}$ Brix (Vásquez-Caicedo et al. 2002) and $\mathrm{pH}$ of 4.62 (Santhirasegaram et al. 2015). However, from Table 1 and Figure 1, it was found that ripeness has started as early as week 16 when the m.c., SSC and $\mathrm{pH}$ were approximately $86.46 \%, 17.83^{\circ} \mathrm{Bx}$ and 4.25 , respectively.

During the development and ripening stage, the m.c. of the fruit samples increased. The increase may due to the increase in the osmotic transfer of moisture from peel to pulp (Appiah et al. 2011). As fruits reach maturity, both the sugar-to-acid ratio and soluble sugars increase (Lamsal \& Jindal 2014). Meanwhile the increase in SSC can be attributed to the breakdown of carbohydrate into simple sugar and sugar (Kittur et al. 2001). Additionally, during the ripening process, starch hydrolyses into simple sugars where glucose, fructose and sucrose are dominant in ripe fruits (Ito et al. 1997). The increase in $\mathrm{pH}$ during development and ripening of mango may also due to utilization of acids as respiration substrates (Aina 1990; Dadzie \& Orchard 1997).

\section{CORRELATION BETWEEN M.C. AND PH}

Figure 2 shows the relationship between $\mathrm{pH}$ and m.c. for the mango samples with high linear regression coefficient of determination of 0.953 . To date, the information on the correlation between $\mathrm{pH}$ and m.c. is still lacking. The previous studies on avocado and cucumber (Hodge 2001), as well as on mango (Appiah et al. 2011) reported that $\mathrm{pH}$ value increased with m.c. (i.e. the higher the m.c., the higher the $\mathrm{pH}$ ). Apparently, this study produced results that have good correlation with the previous studies. Leghari et al. (2013) reported the correlation between $\mathrm{pH}$ and acidity in which low acidity correlated with high $\mathrm{pH}$. Equation (3) can be used to predict the $\mathrm{pH}$ values from known values of m.c. The mean relative error obtained using m.c. method was 0.030 as shown in Table 3.

$$
\begin{aligned}
\mathrm{pH}= & -0.0001 \mathrm{~m} . \mathrm{c} .{ }^{4}+0.0388 \mathrm{~m} . \mathrm{c} .^{3}-4.8706 \mathrm{~m} . \mathrm{c} .^{2} \\
& +270.75 \text { m.c. }-5623.9
\end{aligned}
$$

\section{DIELECTRIC PROPERTIES OF MANGO: DIELECTRIC CONSTANT, $\varepsilon$,}

The $\varepsilon$ ' profile of the mango samples followed closely the $\varepsilon$ ' profile of water. For all samples with different percentages of m.c., the $\varepsilon$ ' decreased almost linearly with the increasing frequency from 1.0 to $4.0 \mathrm{GHz}$ as shown in Figure 3(a). Clearly, it can be observed that samples with higher m.c. have higher values of $\varepsilon$ '. This is expected since water is a strong polar solvent (Ryynanen 1995) that has high electric dipole moment due to the separation of charges. Due to the high dipole moment of water molecules, water has extraordinarily high dielectric constant at microwave frequencies. $\varepsilon^{\prime}$ is the ability of the samples to store energy due to electric polarization of water. The higher the operating frequency, the lesser the water molecules will be polarized and thus the lower the value of the $\varepsilon^{\prime}$. Water molecules are able to follow the microwave vibration at low frequency, thus increases the value of $\varepsilon$ '. Contrarily, the molecules are no longer able to follow the microwave

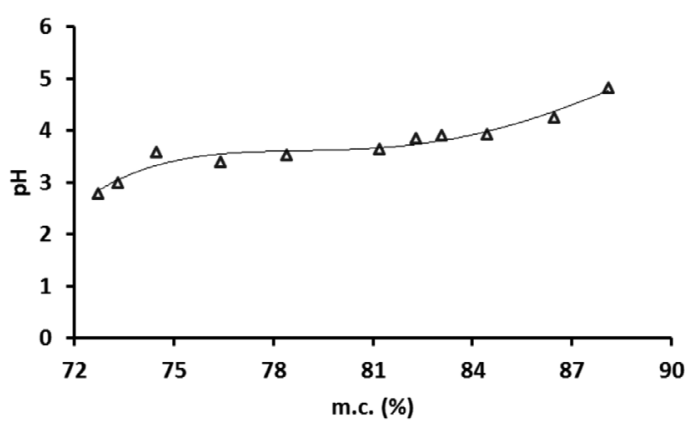

FIGURE 2. The correlation between $\mathrm{pH}$ and m.c. 
TABLE 3. Comparison between actual and predicted $\mathrm{pH}$

\begin{tabular}{cccc}
\hline m.c. $(\%)$ & Actual $\mathrm{pH}$ & Predicted $\mathrm{pH}$ & Relative error \\
\hline 72.88 & 2.75 & 2.84 & 0.033 \\
73.09 & 2.85 & 2.91 & 0.021 \\
74.32 & 3.19 & 3.22 & 0.009 \\
75.56 & 3.13 & 3.40 & 0.086 \\
80.84 & 3.67 & 3.54 & 0.035 \\
81.84 & 3.48 & 3.59 & 0.032 \\
83.45 & 3.73 & 3.78 & 0.013 \\
86.57 & 4.28 & 4.26 & 0.005 \\
87.15 & 4.22 & 4.39 & 0.040 \\
Mean relative error & & 0.030 & \\
\hline
\end{tabular}

vibration at higher frequency and energy is dissipated as heat and resulting in lower values of $\varepsilon$ ' and higher values of $\varepsilon "$ (Kupfer 2005).

\section{DIELECTRIC PROPERTIES OF MANGO: LOSS FACTOR, $\varepsilon "$}

The variation in $\varepsilon$ " with frequency is shown in Figure 3(b). The $\varepsilon "$ describes the ability to dissipate energy in response to an applied electric field or various polarization mechanisms that is a common result in heat generation (Ikediala et al. 2000; Mudgett 1986). $\varepsilon$ " is related to the absorption and dissipation of electromagnetic energy in other forms of energy including thermal (Decareau 1985). These energy absorptions are caused by different factors depending on the structure, composition and frequency.

Obviously from Figure 3(b), it can be observed that $\varepsilon$ " initially decreased at low frequencies before it increased with frequency above a critical frequency, $f_{c}$. $f_{c}$ is the separation frequency between bound and free water regions. Below $f_{c}$ (bound water region) the water molecules were very tightly associated with the mango samples and lesser water movement, which produced the effect of low conductivity value and loss factor. Above (free water region) $\varepsilon "$ closely followed the free water profile. At this region, water molecules moves freely with higher value of conductivity and dissipates as heat energy that in turn increases the values of the loss factor (Ventakesh \& Raghavan 2004). Different percentages of m.c. of the mango samples produced different values of $f_{c}$. For an example, $f_{c}$ for samples with m.c. of $86.46 \%$ and $73.31 \%$ were $1.40 \mathrm{GHz}$ and $1.79 \mathrm{GHz}$, respectively. The effect of m.c. on the $f_{c}$ at various microwave frequencies can be seen clearly in Figure 4. The values of $f_{c}$ decreased linearly with the increasing percentage of m.c. in the samples where:

$$
f_{c}=-0.0243 \text { m.c. }+3.5349
$$

The values of $\varepsilon$ " for all samples were the lowest at $f$. For example, mango samples with $78.39 \%$ m.c., the corresponding values of $\varepsilon$ " were 13.97 at $1.63 \mathrm{GHz}$.
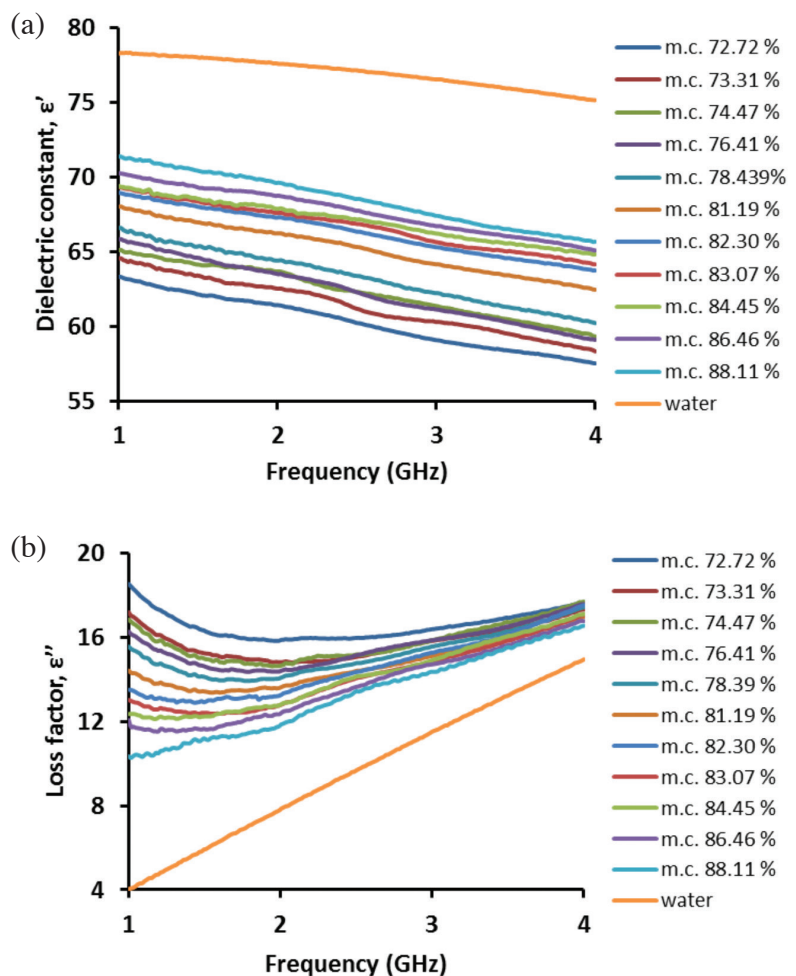

FIGURE 3. Variations in (a) $\varepsilon$ ' and (b) $\varepsilon$ "with frequency at 11 values of m.c

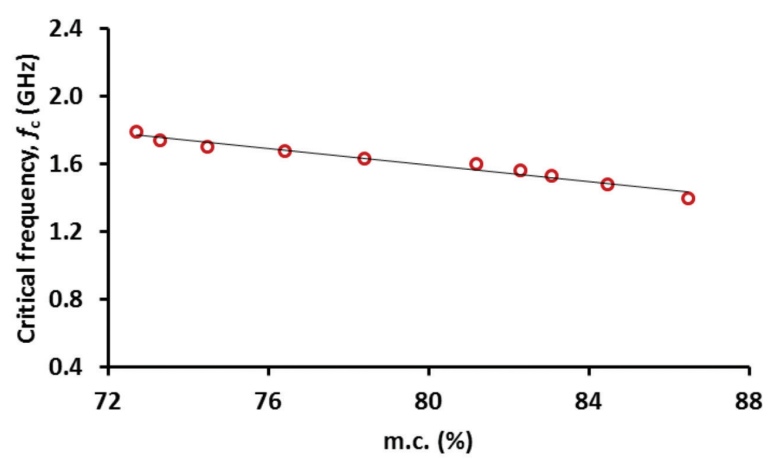

FIGURE 4. Relationship between and m.c. 


\section{CORRELATION BETWEEN PERMITTIVITY AND QUALITY INDICES}

For moist samples with constant $\mathrm{pH}$, the permittivity ( $\varepsilon$ ' and $\varepsilon "$ ) increases with the increasing values of m.c. (Ansaruddin et al. 2012). The higher the amount of m.c. in the samples, the stronger the binding between hydrogen and oxygen molecules will be. Water is highly polarized material (Hasted 1973), thus samples with higher m.c. will be more polarized that in turn will increase $\varepsilon$ '. Samples with higher m.c. will allow more free movement of the water molecules and may result higher energy dissipation due to the greater effect of dipole polarization. Thus, the $\varepsilon$ " increases for samples with higher m.c. However, in the study, $\mathrm{pH}$ for mango samples increased with m.c. during fruit development and ripening process as discussed in previous section. The higher the m.c., the higher the $\mathrm{pH}$ values and the lower the conductivity values will be, which in turn will decrease the $\varepsilon$ " values (Thumm et al. 2012).

The relationship between $\varepsilon$ ' and $\varepsilon$ "with m.c. is summarized at four arbitrary frequencies: 1.0, 2.0, 3.0 and $4.0 \mathrm{GHz}$ as shown in Table 4 . The value of the $\mathrm{R}^{2}$ and $\varepsilon$ ' decreased as the frequency increased. Table 4 suggests higher $\mathrm{R}^{2}$ values may be obtained at lower frequencies due to the orientation polarization of polar molecules was slowed down by the binding of water molecules in the mixture. At low frequency, the water molecules were tightly bound with the composition in the samples, thus they would be able to follow the microwave vibration and more water molecules would be polarized. The sensitivity that is the gradient of the regression line is defined as the change in the output ( $\Delta^{\prime}$ or $\left.\Delta^{\prime \prime}\right)$ with respect to the input ( $\Delta$ m.c.). The range of sensitivities $\Delta^{\prime} / \Delta$ m.c. were from 0.4854 to 0.5408 . The sensitivities, $\Delta " / \Delta$ m.c. were much lower ranging between 0.4598 and 0.0536 . The equations in Table 4 can be used to determine both $\varepsilon$ ' and $\varepsilon$ " from known m.c. values. Inversely, the permittivity values obtained using the Keysight coaxial probe can be used to predict m.c. in the mango samples by exchanging the $\varepsilon$ ' and $\varepsilon "$ with m.c. in the $x-y$ graph.

\section{PERFORMANCE ANALYSIS}

An equation with high regression coefficient does not necessarily produce high accuracy prediction results. Accurate results can only be determined by comparing the predicted m.c. results obtained indirectly from the dielectric measurements with the actual m.c. found using the microwave oven method (Ansarudin et al. 2012).

The calibration equations at the four selected frequencies for the determination of m.c. based on the dielectric properties are tabulated in Table 5. The calibration equations based on both $\varepsilon$ ' and $\varepsilon$ " were found to be the most accurate at $1.0 \mathrm{GHz}$. The lowest mean relative error of 0.017 was obtained using $\varepsilon^{\prime}$ method compared to $\varepsilon$ " method (0.024), both values at $1.0 \mathrm{GHz}$. Thus, it can be concluded that the most accurate equation to predict m.c. in the mango samples is based on the measurement of the

TABLE 4. Relationship between $\varepsilon$ ' and $\varepsilon$ " with m.c.

\begin{tabular}{ccccc}
\hline $\begin{array}{c}\text { Frequency } \\
(\mathrm{GHz})\end{array}$ & $\varepsilon^{\prime}$ & $\mathrm{R}^{2}$ & $\varepsilon^{\prime \prime}$ & $\mathrm{R}^{2}$ \\
\hline 1 & $\varepsilon^{\prime}=0.4821$ m.c. +28.927 & 0.985 & $\varepsilon^{\prime \prime}=-0.4684$ m.c. +52.071 & 0.979 \\
2 & $\varepsilon^{\prime}=0.5054$ m.c. +25.258 & 0.976 & $\varepsilon^{\prime \prime}=-0.2192$ m.c. +31.253 & 0.955 \\
3 & $\varepsilon^{\prime}=0.5297$ m.c. +21.180 & 0.972 & $\varepsilon^{\prime \prime}=-0.1109$ m.c. +24.236 & 0.939 \\
4 & $\varepsilon^{\prime}=0.5542$ m.c. +17.481 & 0.966 & $\varepsilon^{\prime \prime}=-0.0684$ m.c. +22.729 & 0.922 \\
\hline
\end{tabular}

TABLE 5. Calibration equation relating m.c. to (a) dielectric constant, $\varepsilon$ ' and (b) loss factor, $\varepsilon$ "'

(a)

\begin{tabular}{cccc}
\hline Frequency $(\mathrm{GHz})$ & $\mathrm{R}^{2}$ & Calibration equation & Mean relative error \\
\hline 1 & 0.985 & m.c. $=2.0421^{\prime}-57.826$ & 0.017 \\
2 & 0.976 & m.c. $=1.9313^{\prime}-46.868$ & 0.019 \\
3 & 0.972 & m.c. $=1.8346^{\prime}-36.593$ & 0.271 \\
4 & 0.966 & m.c. $=1.7430^{\prime \prime}-27.748$ & 0.299 \\
\hline
\end{tabular}

(b)

\begin{tabular}{cccc} 
Frequency $(\mathrm{GHz})$ & $\mathrm{R}^{2}$ & Calibration equation & Mean relative error \\
\hline 1 & 0.979 & m.c. $=-2.0891 ”+110.50$ & 0.024 \\
2 & 0.955 & m.c. $=-4.3573 ”+139.78$ & 0.053 \\
3 & 0.939 & m.c. $=-8.4713 ”+210.19$ & 1.215 \\
4 & 0.922 & m.c. $=-13.466 "+312.34$ & 2.348 \\
\hline
\end{tabular}




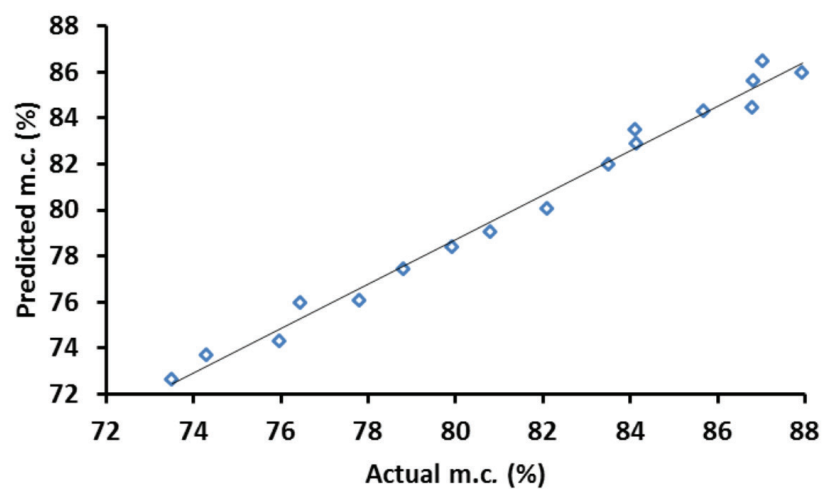

FIGURE 5. Direct comparison between predicted m.c. and actual m.c. at $1.0 \mathrm{GHz}$ using calibration equation and microwave oven drying method, respectively

$\varepsilon$ at $1.0 \mathrm{GHz}$. Figure 5 directly compares the predicted and actual m.c.

\section{CONCLUSION}

An open-ended coaxial technique suitable for the determination of m.c. and $\mathrm{pH}$ of mango has been developed and tested. The dielectric constant and loss factor were used to determine the m.c. that in turn was used to predict the $\mathrm{pH}$ of mango samples from week 5 to 17 during fruit development. The technique is a nondestructive and suitable for a speedy initial quality check of fruit ripeness. A portable microwave measurement system shall be constructed soon to replace the VNA for in situ measurements.

\section{ACKNOWLEDGEMENTS}

This research was supported by the Ministry of Higher Education (MOHE), Malaysia through Fundamental Research Grant Scheme (FRGS/1/2015/TK02/MOA/02/1). The authors would like express utmost gratitude to the Malaysian Agricultural Research and Development Institute (MARDI) and Universiti Putra Malaysia (UPM) for the use of facilities for the research. The gratitude is also extended to MARDI Research Station, Kundang for the mango samples and for the staff assistance during the sampling process. Finally, thanks to Mr. Fadhilnor Abdullah (MARDI Perlis) for his assistance with data interpretation.

\section{REFERENCES}

Abidin, M.I.Z. 1991. Pengeluaran Buah-buahan. Kuala Lumpur: Dewan Bahasa dan Pustaka.

Agilent Technologies. 2013. Agilent 85070E Dielectric Probe Kit. California: Agilent Technologies Inc.

Aina, J.O. 1990. Physico-chemical changes in African mango (Irvingia gabonensis) during normal storage ripening. Food Chemistry 36: 205-212.

Ansarudin, F., Abbas, Z., Hassan, J., Yahaya, N.Z. \& Ismail, M.A. 2012. A simple insulated monopole sensor technique for determination of moisture content in Hevea rubber latex. Measurement Science Review 12: 249-254.
AOAC. 2000. Official Methods of Analysis of the Association of Official Analytical Chemists. 17th ed. Arlington VA: AOAC International.

AOAC. 1990. Official Methods of Analysis of the Association of Official Analytical Chemists. 15th ed. Arlington VA: AOAC International.

Appiah, F., Kumah, P. \& Idun, I. 2011. Effect of ripening stage on composition, sensory qualities and acceptability of Keitt mango (Mangifera indica L.) chips. African Journal of Food, Agriculture, Nutrition and Development 11: 5096-5109.

Blackham, D.V. \& Pollard, R.D. 1997. An improved technique for permittivity measurements using a coaxial probe. IEEE Trans. on Instrumentation and Measurement 46: 1093-1099.

Bouraoui, M., Richard, P. \& Fichtali, J. 1993. A review of m.c. determination in foods using microwave oven drying. Food Research International 26: 49-57.

Dadzie, B.K. \& Orchard, J.E. 1997. Routine Post-Harvest Screening of Banana/Plantain Hybrids: Criteria and Methods. Italy: International Plant Genetic Resources Institute.

Decareau, R.V. 1985. Microwaves in the Food Processing Industry, Series of Food Science and Technology. New York: Academic Press.

Ding, P. \& Darduri, K.B. 2013. Morphology of Chok Anan mango flower grown in Malaysia. African Journal of Agricultural Research 8: 1877-1880.

Guardiola, J.L. 1997. Overview of flower bud induction, flowering and fruit set. In Citrus Flowering and Fruit Short Course, edited by Futch, S.H. \& Kender, W.J. April, at Citrus Research and Education Center, UF/IFAS, Lake Alfred, FL. pp. 5-21, pp. 9-10.

Guo, W., Zhu, X., Nelson, S.O., Yue, R., Liu, H. \& Liu, Y. 2011 Maturity effects on dielectric properties of apples from 10 to 4500 MHz. LWT - Food Science and Technology 44: 224-230.

Hasted, J.B. 1973. Aqueous Dielectric. London: Chapman and Hall.

Hodge, S. 2001. The effect of $\mathrm{pH}$ and water content of natural resources on the development of Drosophila melanogaster larvae. Dros. Inf. Serv. 84: 38-43.

Ikediala, J.N., Tang, J., Drake, S.R. \& Neven, L.G. 2000 Dielectric properties of apple cultivars and codling moth larvae. American Society of Agricultural Engineers 43: 1175-1184

Ito, T., Sasaki, K. \& Yoshida, Y. 1997. Changes in respiration rate, saccharide and organic acid content during the development 
and ripening of mango fruit (Mangifera indica L. 'Irwin') cultured in a plastic house. Journal of the Japanese Society for Horticultural Science 66: 629-635.

Kittur, F., Saroja, N., Habibunnisa \& Tharanathan, R.N. 2001. Polysaccharide-based composite coating formulations for shelf-extension of fresh banana and mango. European Food Research and Technology 213: 306-311.

Lamsal, B.P. \& Jindal, V.K. 2014. Variation in electrical conductivity of selected fruit juices during continuous Ohmic heating. International Journal of Applied Science and Technology 7: 47-56.

Leghari, M.H., Ahmed, S.S., Meman, N.U.N., Soomro, A.H. \& Khooharo, A.A. 2013. Quality attributes of immature fruit of different mango varieties. Journal of Basic \& Applied Sciences 9: 52-56.

Michael, D., Mingos, P. \& Baghurst, D.R. 1991. Application of microwave dielectric heating effects to synthetics problems in chemistry. Chem. Soc. Rev. 20: 1-47.

Mudgett, R.E. 1986. Electrical properties of foods. In Engineering Properties of Foods, edited by Rao, M.A. \& Rizvi, S.S.H. New York: CRC Press. pp. 329-390.

Nielsen, S.S. 2010. Food Analysis. 4th ed. USA: Springer.

Nelson, S.O. 2003. Frequency- and temperature-dependent permittivities of fresh fruits and vegetables from 0.01 To 1.8 GHz. Transactions of the ASAE 46: 567-574.

Padda, M.S., Amarante, C.V.T., Garciac, R.M., Slaughter, D.C. \& Mitchama, E.J. 2011. Methods to analyzephysico-chemical changes during mango ripening: A multivariate approach. Postharvest Biol. Technol. 62: 267-74.

Pleguezuelo, C.R.R.,Zuazo, V.H.D., Fernandez, J.L.M. \& Tarifa, D.F. 2012. Physico-chemical quality parameters of mango (Mangifera indica L.) fruits grown in a Mediterranean subtropical climate (SE Spain). J. AgriSci. Tech. 14: 365-374.

Quintana, E.G., Nanthachai, P., Hiranpradit, H., Mendoza Jr, D.B. \& Ketsa, S. 1984. Changes in mango during growth and maturation: Growth and development of mango. In Mango Fruit Development, Postharvest Physiology and Marketing in ASEAN, edited by Mendoza, D.B. \& Wills, R.B.H. Kuala Lumpur: ASEAN Food Handling Bureau. pp. 21-27.

Ragni, L., Gradari, P., Berardinelli, A., Giunchi, A. \& Guarnieri, A. 2006. Predicting quality parameters of shell eggs using a simple technique based on the dielectric properties. Biosystems Engineering 94: 255-262.

Ryynanen, S. 1995. The electromagnetic properties of food materials: A review of basic principles. Journal of Food Engineering 27: 409-429.

SAS Institute. 1989. SAS/STAT User's Guide. Cary: SAS Institute. Santhirasegaram, V., Razali, Z., George, D.S. \& Somasundram, C. 2015. Comparison of UV-C treatment and thermal pasteurization on quality of Chok Anan mango (Mangifera indica L.) juice. Food and Bioproducts Processing 94: 313-321.

Shofian, N.M., Hamid, A.A.B., Osman, A., Saari, N., Anwar, F.C., Dek, M.S.P. \& Hairuddin, M.R. 2011. Effect of freeze-drying on the antioxidant compounds and antioxidant activity of selected tropical fruits. International Journal of Molecular Sciences 12: 4678-4692.
Soltani, M., Alimardani, R. \& Omid, M. 2011. Use of dielectric properties in quality measurement of agricultural products. Nature and Science 9: 57-61.

Sosa-Morales, M.E., Tiwari, G., Wang, S., Tang, J., Gancia, H.S. \& Lopez-Malo, A. 2009. Dielectric heating as a potential postharvest treatment of disinfesting mangoes, Part I: Relation between dielectric properties and ripening. Biosystems Engineering 103: 297-303.

Thumm, M., Wiesbeck, W., Note, A., Huisman, J.A., Thakur, O.P., Singh, A.K. \& Authority, S. 2012. The relationship between loss, conductivity, and dielectric constant. Advanced Studies in Theoretical Physics 46: 1-12.

Vásquez-Caicedo, A.L., Neidhart, S., Pathomrungsiyounggul, P., Wiriyacharee, P., Chattrakul, A., Sruamsiri, P., Manochai, P., Bangerth, F. \& Carle, R. 2002. Physical, chemical and sensory properties of nine Thai mango cultivars and evaluation of their technological and nutritional potential. International Symposium Sustaining Food Security and Managing Natural Resources in Southeast Asia.pp. 1-13.

Yahaya, N.Z., Abbas, Z., Ibrahim, N.M., Hafizi, M.H.M. \& Yahaya, M.Z. 2014. Permittivity models for determination of moisture content in Hevea Rubber Latex. International Journal of Agricultural and Biological Engineering 7: 48-54.

Noradira Suhaime, Masniza Sairi, Zulkifly Abbas*, Nur Biha Mohamed Nafis, Suriati Paiman \& Tity Nazleen Mohamed Department of Physics Faculty of Science Universiti Putra Malaysia 43400 UPM Serdang, Selangor Darul Ehsan Malaysia

Masniza Sairi, Amir Syariffuddeen Mhd Adnan \& Amir Redzuan Shamsulkamal Engineering Research Center Malaysian Agricultural Research and Development Institute (MARDI)

MARDI Headquarters, Persiaran MARDI-UPM

43400 UPM Serdang, Selangor Darul Ehsan

Malaysia

\section{Zaulia Othman}

Bank Gene and Seed Center

Malaysian Agricultural Research and Development Institute (MARDI)

MARDI Headquarters, Persiaran MARDI-UPM

43400 UPM Serdang, Selangor Darul Ehsan Malaysia

*Corresponding author; email: za@upm.edu.my

Received: 14 December 2017

Accepted: 20 February 2018 